\title{
Understanding Postgraduate Student Preferences for University Choice in Zambia: The Case of ZCAS University
}

\author{
Kelvin Mukolo Kayombo ${ }^{1}$, Gwebente Mudenda ${ }^{2}$, Burton Mweemba ${ }^{3}$, Janis Nduli ${ }^{4}$ \\ ${ }^{1}$ Department of Accountancy, ZCAS University, Lusaka, Zambia \\ ${ }^{2}$ Department of Management Studies, ZCAS University, Lusaka, Zambia \\ 3\&4Zambia Centre for Accountancy Studies, Lusaka, Zambia \\ kkayombo@zcas.edu.zm,gwebente.mudenda@zcas.edu.zm, burton.mweemba@zcas.edu.zm, \\ jnduli@zcas.edu.zm
}

\begin{abstract}
The aim of this study was to ascertain the university brand model that characterizes postgraduate student choice of ZCAS University. The brand model comprises brand attributes that attract postgraduate students to the university, the information sources they consult, who influences their decisions and what makes the university unique. The study was qualitative in design, while sampling of research participants was done purposively. Three focus group discussions involving seventeen first years part time and open distance e-learning postgraduate students, and five semi-structured interviews with marketing and recruitment staff at ZCAS University were used to collect data on the brand model. Thematic analysis and content analysis were then used as the primary data analysis techniques. Results of the study revealed that reputation, teaching quality, student support, fees and facilities were the top five ZCAS University brand traits that underpin postgraduate students' choice of the university. With respect to competitive advantage, facilities, teaching quality reputation and accreditations are perceived to be the university's primary unique characteristics. The study further identified friends, self, workmate and family as the greatest influencers of postgraduate student choice of the university; while websites, social media, print media and television are believed to be the most consulted information sources by prospective postgraduate students.
\end{abstract}

Keywords: University Brand, Information Sources, Postgraduate, Influencers, ZCAS University, Competitive Advantage.

\section{Introduction}

ZCAS University was established as a private university in Zambia in December 2016 (ZCAS University, 2017). The university inherited several undergraduate and postgraduate degree programmes that were hitherto run by the Zambia Centre for Accountancy Studies (ZCAS), the parent company. The university was established to take advantage of the rise in demand for university education in the country, as well as to mitigate the continuing reduction in student enrollment on professional programmes offered by the parent company. It is generally acknowledged in the higher education (HE) marketing literature that competition for university students has continued to rise (Hemsley-Brown \& Oplatka, 2006). In Zambia, for example, there are currently 62 registered universities (Higher Education Authority, 2019). This represents a significant rise in competition in the sector, given that there were just 3 registered universities 17 years ago. Like ZCAS University, most of the higher education institutions (HEIs) in Zambia offer business related programmes. This implies that the university is operating in a highly competitive market. However, this study did not address the specific attributes relevant to aspiring postgraduate students.

In order to grow and thrive as a new HEI, ZCAS University needs to strengthen its brand image in order to become more visible and increase its market share. The university, in particular, needs to ascertain the HE brand models that characterize student choice of university. Such a brand model comprises brand attributes that attract students to the university, the information sources they consult, who influences their university choice decisions and what makes the university unique. Several studies have been carried out to explore the positioning of HEIs in the market for postgraduate studies in various parts of the world (Zhu \& Reeves, 2019). In the case of Zambia, there is a dearth of such research in the postgraduate market. The HE market, just like many other markets, is segmented on the basis of demographic, geographic, social and behavioral factors (Hemsley-Brown \& Oplatka, 2015); therefore, HE brand models identified in other countries may have differing elements from the Zambian market. For example, the factors that motivated students to pursue an MBA programme differed significantly between Indian university students and their Kenyan counterparts (Nyaribo, Prakash, \& Owino, 2012). 
A study that focuses on the postgraduate market in Zambia is therefore required. A study carried out in Zambia proposed a university brand model relevant to the market for undergraduate studies (Kayombo \& Carter, 2016). The postgraduate market is very important to ZCAS University because of the large alumni base of former students who pursed professional qualifications at ZCAS. These potential students can easily be lured to pursue master's degree programmes at the university. It is therefore necessary that a positioning study is carried out to equip ZCAS University marketers with context specific knowledge regarding the HE brand model for the postgraduate market in the country. Such knowledge would help in developing customized marketing activities for this unique HE subsector. Accordingly, the current study set out to identify the foremost university branding factors that underpin postgraduate student choice of ZCAS University. In view of this, the research question designed to guide the study was: How can a university brand be identified and used for competitive positioning in the market for postgraduate studies in Zambia? The rest of the paper is organized as follows: a discussion of the literature review is provided in the next section, followed by justification of the research methodology. Presentation and discussion of findings follow thereafter; and finally, concluding remarks, recommendations, limitations of the study and directions for future research are presented.

\section{Literature Review}

Despite earlier doubts regarding applicability of brand management principles and practices in higher education (Chapleo, 2010), the case for managing universities as brands has continued growing from strength to strength (Furey, Springer, \& Parsons, 2014). The subsections below review the literature on university brand positioning, university brand factors, sources of competitive advantage for universities, information sources and influencers of student choice of university.

Brand Positioning: Brand positioning can be considered to be activities an organization implements to position itself in a preferable place in a potential customer's mind (Dibb, Simkin, Pride, \& Ferrell, 2006). Ries and Trout posit that brand positioning can be applied to anything ranging from an institution, goods, services, company, and even a person (Ries \& Trout, 2001). With respect to this study, ZCAS University as a newly established HEI needs to position itself in favourable light in the minds of prospective and existing customers. The university could therefore aim to position itself, its schools, programmes it offers and even eminent staff such as the Vice Chancellor. However, to achieve this positioning effectively, the university must identify attributes that lure potential learners to HEIs. Accordingly, these factors are discussed in the sections below.

Higher Education Branding Factors: Many studies have been carried out to identify factors that inform prospective leaners' choice of postgraduate programmes, particularly the MBA programme (Saiti, Papa, \& Brown, 2017). However, there is a paucity of research on institutional factors that aspiring postgraduate candidates consider. Ivy identified seven university brand elements that MBA students considered in their choice of South African universities (Ivy, 2008). These included programme (course content), prominence (reputation), price (fees and payment plan), prospectus (direct mail promotions and direct mail from university) and people (face to face tuition and contact with peers) as the most prominent elements. Promotion and premiums (infrastructure and facilities) were identified as relevant elements but not prominent. Additionally, the research was conducted in one or a few universities only, thereby limiting generalization of findings to other contexts.

In China, potential postgraduate students considered personal interest, employability, good income prospects, entry requirements, reputation, location, teaching quality and facilities as factors that underpinned their choice of a Chinese University (Liu \& Morgan, 2015). In the UK the following choice criteria for potential postgraduate students (in order of importance) were unveiled (Soilemetzidis, Bennett, \& Leman, 2014): HEI location, HEI reputation, course content and reputation of the subject area/department. More recently, comparable postgraduate decision making factors in UK universities that include fees, course content, location, infrastructure, speedy response, reputation, internships opportunities/work placements, accreditations, and practical nature of the course were unveiled (Towers \& Towers, 2018). With respect to choice of foreign universities, quality of education, scholarship, quality of academic staff, study program, practice, tuition fee, standard of living in the state, rank and location were identified as key factors that potential postgraduate students. 
Sources of Competitive Advantage: Several researchers have considered and studied the need for HEIs to employ strategies for gaining and sustaining competitive advantage (Kayombo \& Carter, 2016). Local HEIs, for example, need to contend with strong international brands looking to sustain their leadership positions (Lomer, Papatsiba, \& Naidoo, 2018). Accordingly, well established HEIs need to continuously innovate to sustain their leadership positions, while those hoping to become global brands can use competitiveintegrative benchmarking to learn from the strong brands and create their own strategic advantages (Ganushchak-Yefimenko, Shcherbak, \& Nifatova, 2017). This can be accomplished by finding interfaces for cooperating with other institutions in order to benefit from their experience. Competitive advantage was defined as "the achievement of superior performance vis-à-vis rivals, through differentiation, to create distinctive product appeal or brand identity" (Dibb, Simkin, Pride, \& Ferrell, 2006). HEIs can gain competitive advantage by differentiating their service offerings to ensure that they satisfy their internal and external consumers better than competitors (Al Shobaki \& Abu Naser, 2017). This differentiation is accomplished by building brands out of two main constructs: quality educations by retaining good service delivery staff and other conditions; and thereafter, ensuring good prospects for graduates (Lomer, Papatsiba, \& Naidoo, 2018).

Although these studies addressed postgraduate contexts, a limitation in main cases is that the sample sizes were quite small. A reported study carried out in Zambia suggested that typical sources that HEI can exploit to gain competitive advantage include availability of courses, quality of teaching, facilities and infrastructure. However, this study did not address issues relevant to the postgraduate market. In the postgraduate studies market, institutions can further get competitive advantage from employability of graduates (which is a reflection of the quality of the institutions' programmes), local and international recognition or rankings, consistency of service delivery through proper leveraging of integrated management systems such as ERP which can improve cost management, and resource efficiency of administrative procedures (Soliman \& Karia, 2017). Other researchers further assert that effective relationship management for both recruiting and retaining students is another potential source of competitive advantage in the market for postgraduate studies (Chaguluka, Beharry-Ramraj, \& Amolo, 2018). Although the findings in the preceding studies relate to postgraduate students, their contexts are different to Zambia. Therefore, it is not feasible to generalize the findings to the market for postgraduate studies in Zambia.

Information Sources: It has long been established that potential students search for information when making university related decisions (Nicholls, Harris, Morgan, Clarke, \& Sims, 1995). The literature search found few published studies regarding information sources consulted by aspiring postgraduate students. The review suggested the following as the most commonly consulted sources for information by prospective postgraduate students: social media such as Facebook, LinkedIn, and Instagram (Galan, Lawley, \& Clements, 2015); Internet (AL-Mutairi \& Saeid, 2016), and friends and family (AL-Mutairi \& Saeid, 2016). Other information sources include print media (AL-Mutairi \& Saeid, 2016); university agents (Moogan, 2018); and alumni, campus visit, and education expos (AL-Mutairi \& Saeid, 2016). In the case of Zambia, there is no reported study in the context of the postgraduate market. Higher education marketers may therefore be unaware of the most suitable medium to provide sufficient and relevant information to aid prospective postgraduate students' choice of university. Marketing efforts may therefore not be bearing fruit as they are not focused on provision of sufficient and relevant information that is based on empirical research (Carter \& Yeo, 2009).

Influencers of Student Choice of University: Influencers of student choice of university are people who influence decision making by encouraging potential students to choose particular universities or programmes. Knowing who influences student choice of university should be essential to brand and recruitment strategists because such knowledge can be used to provide marketing information to relevant influencers. There are few reported studies on influencers of prospective postgraduate students globally. Parents have been identified as influencers of postgraduate student choice in various studies such as (Liu \& Morgan, 2015), (Moogan, 2018), (Nyaribo, Prakash, \& Owino, 2012) and (Towers \& Towers, 2018). Other prolific influencers identified include alumni and current students (Towers \& Towers, 2018), friends (Nyaribo, Prakash, \& Owino, 2012), college teachers (Nyaribo, Prakash, \& Owino, 2012), and university agents (Towers \& Towers, 2018). In Zambia, friends, parents and self were identified as the most prolific influencers of university choice (Kayombo \& Carter, 2016). However, this study did not include potential or current postgraduate students. 
Gaps in the Postgraduate Market Branding Literature: The review of the literature has revealed that although research has been conducted to unveil the postgraduate market brand model in other parts of the world, there is a paucity of such research in the African context. HE marketers may therefore fail to target their marketing messages at the most prolific influencers of prospective postgraduate students. In particular, there are no published studies that attempt to conceptualize or operationalize the following university brand orientation dimensions in respect of the market for postgraduate programmes in Zambia:

- The university brand attributes aspiring postgraduate students consider when choosing a university;

- The sources of sustainable competitive advantage in the market for postgraduate students;

- The information sources that potential postgraduate students consult in search of information about universities;

- The influencers of aspiring postgraduate students.

The current research aims at filling this gap in the literature by answering the following research question: How can a university brand be identified and used for competitive positioning in the market for postgraduate programmes in Zambia? To answer the research question above, the following objectives were designed:

R01: Ascertain brand attributes that enhance a university's position in the postgraduate studies market in Zambia.

R02: Establish ZCAS University's brand position in the postgraduate studies market in Zambia.

R03: Recommend strategies that ZCAS University's management should implement to enhance the university's brand position in the postgraduate studies market in Zambia.

\section{Research Methodology}

The methodology adopted to implement the study is outlined in this section. The study adopted a qualitative design. A case study strategy was chosen to implement the study. Semi-structured interviews with ZCAS University marketing executives and recruitment staff were conducted to collect data. Data were also collected from purposively sampled ZCAS University first year postgraduate focus group participants. The data were then analyzed using thematic and content analysis techniques. The research procedure is illustrated in Figure 1 below, followed by justification of the research methodology.

Case Study Strategy: A case study has been defined as "a strategy for doing research which involves an empirical investigation of a particular contemporary phenomenon within its real life context using multiple sources of evidence" (Robson, 2002). A case study strategy enables researchers to understand an issue in its totality and world context (Saunders, Lewis, \& Thornhill, 2016). This finding is in agreement with research undertaken in the context of choice of a Chinese university (Liu \& Morgan, 2015). Facilities were also identified as an important factor that MBA students took into account when choosing South African universities (Ivy, 2008). As stated above, the HE sector in the country is still developing, hence most of the HEIs, including public universities, lack adequate facilities to support postgraduate study. Course content or structure was not highly regarded as a factor in student choice of university, although it received higher weightings in prior studies such as (Cvetkoska, 2019), (Ivy, 2008), and (Soilemetzidis, Bennett, \& Leman, 2014). The choice of the case study strategy for this research is buttressed by several similar HE brand positioning studies such as (Blackburn, 2011), (Khalifa, Dukhan, \& Mouselli, 2017), and (Liu \& Morgan, 2015).

Sampling Frame and Sample Size: This study's sampling frame included ZCAS University marketing and recruitment staff and first year postgraduate students who had just made a decision to study at the University. Three or $60 \%$ of the 5 most experienced recruitment staff and both of the marketing executives were interviewed. University marketing executives, instead of other administrators, were interviewed as they play a key role in directing and controlling HEIs' brand management. Similar HEI branding studies have focused on university marketing experts as a source of information on brand related issues (Chapleo, 2010). In the Republic of Macedonia considered in their choice of universities abroad (Cvetkoska, 2019). Some of these factors, e.g. financial costs and academic image, were identified as being important for potential Chinese students seeking postgraduate training abroad (Zhu \& Reeves, 2019), other factors unveiled included employability, reputation, language, culture, visa, admissions and weather. In order to triangulate data collection sources, 3 focus group discussions were conducted. The focus groups involved 17 of the 92 first 
year part time and open distance e-learning (ODeL) postgraduate students who joined the university in the previous 3 months.

Figure 1: Research Procedure: Adapted from (Kayombo K. M., 2014)

Literature based brand orientation components (from Literature Review)

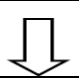

Develop focus group discussion (FGD) and semi-structured interview schedules

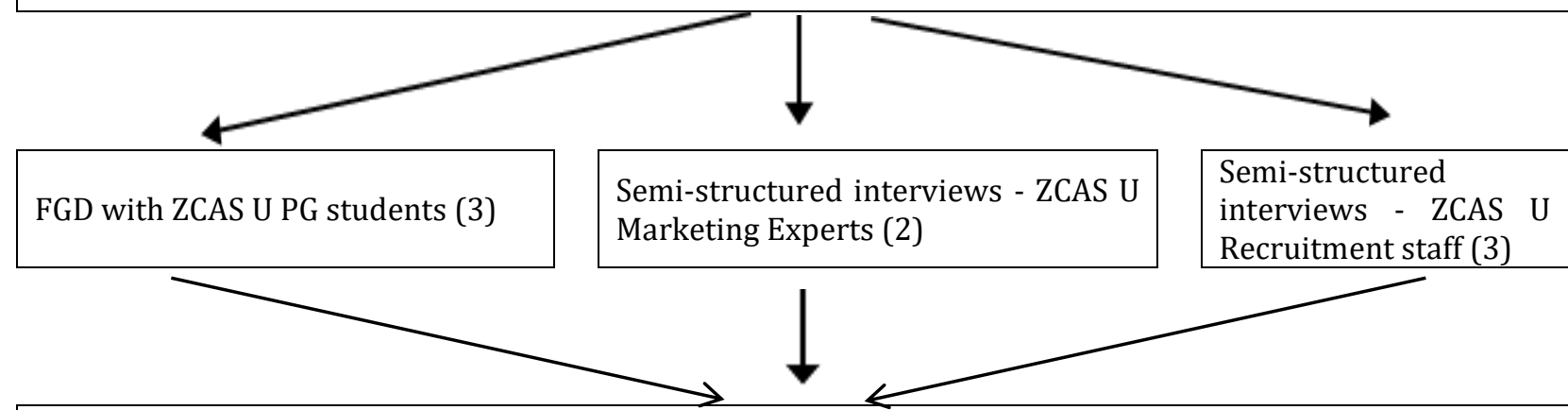

Thematic analysis, data coding and content analysis using Atlas.ti software

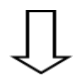

Principal ZCAS University brand orientation components

Purposive sampling was used to select the focus group participants because this sampling technique ensures that only relevant information rich population units are included in the sample (Saunders, Lewis, \& Thornhill, 2016). The choice of this sampling technique is buttressed my many similar studies (Kayombo \& Carter, 2016). The 3 focus groups comprised distinct categories of students. The focus groups comprised part time students on ZCAS University masters' degree programmes, part time postgraduate students on foreign programs, and ODeL students. Grouping participants based on status and experience enhances their participation in the deliberations (Saunders, Lewis, \& Thornhill, 2016). First year students were considered more suitable as a source of data because they had just made the university choice. They were therefore more likely to have fresher memories of the brand dimensions considered than returning students. Similar HEI branding studies have focused on first year students as a source of information about university choice (Carter \& Yeo, 2009).

Data Collection: Researchers conducted semi-structured interviews and focus group discussions to collect data. These data collection techniques have been used in similar HEI branding studies such as (Liu \& Morgan, 2015), (Towers \& Towers, 2018), and (Zhu \& Reeves, 2019). Three focus group discussions comprising 17 first year part time and ODeL postgraduate students who had recently joined the university were conducted. Focus group discussions were considered suitable because research participants challenge each other and discuss issues they consider important (Bryman \& Bell, 2011). The focus groups technique is also considered 'naturalistic' because it echoes how people collectively make sense of phenomena. In addition, data were collected from business development and recruitment staff in the university by means of 5 semi-structured interviews. The use of semi-structured interviews in qualitative research is recommended because the technique enhances understanding by asking "what" and "how" questions (Saunders, Lewis, \& Thornhill, 2016). Semi-structured interviews also enhance understanding by exploring the "why" issue. 
Data Processing: The researchers recorded and transcribed the interviews and focus group discussions. Thereafter, they used Atlas.ti software to process the data. This involved data coding and creating quotations, memos, families and networks to facilitate content analysis. The researchers used thematic analysis to identify codes or themes from the focus group discussions and interviews. Thematic analysis is the "search for themes, or patterns, that occur across a data set" (Saunders, Lewis, \& Thornhill, 2016). The technique was employed to identify recurring themes that indicated university brand factors aspiring postgraduate students considered when choosing the university. The themes or codes identified in this process were then synthesized with those that emerged from the review of the literature. Subsequently, the codes or branding elements were used to categorize the interview and focus group data to facilitate content analysis. The use of thematic and content analysis in HE brand management studies is very common (Kayombo K. M., 2014).

Reliability and Validity: Several techniques were employed to enhance reliability during the data collection process. For example, researchers used focus group and interview guides, and provided research participants with question schedules in advance of the interview (Saunders, Lewis, \& Thornhill, 2016). In addition, researchers took notes during the discussions and adapted interview questions from similar studies (AliChoudhury, Bennet, \& Savani, 2009). Furthermore, multiple data sources and data collection techniques were used to achieve triangulation (Lee \& Lings, 2013). For example, data were collected from different sources such as postgraduate students and marketing executives. Additionally, multiple techniques such as focus group discussions and semi-structured interviews were used in data collection.

\section{Findings and Analysis}

As indicated above, the aim of the study was to identify the principal HE branding factors that characterize postgraduate student choice of ZCAS University. These include brand factors the students considered, their perceived source of the university's competitive edge, the information sources they consulted and who influenced their choices. This section is therefore presented on the basis of these branding dimensions.

Higher Education Branding Factors: The study identified 19 variables that aspiring postgraduate students considered in their choice of ZCAS University (see Figure 2 below). Results of content analysis indicated that the most considered branding factors by aspiring postgraduate students at ZCAS University were reputation, teaching quality, student support, fees and facilities. Other factors identified include culture, credibility, employability, course availability, timely completion, course structure, environment, delivery mode, infrastructure, location and pass rates. Mission and vision, ease of entry and return on investment were insignificant, jointly accounting for only $1 \%$ of brand factor considerations. The brand factors identified in this study are comparable to those unveiled in other empirical studies elsewhere. For example, brand factors such as reputation, teaching quality, fees and facilities that postgraduate students at ZCAS University valued the most were also prominent in other studies such as (Ivy, 2008), (Liu \& Morgan, 2015), and (Soilemetzidis, Bennett, \& Leman, 2014). In the current study, potential postgraduate students seem preoccupied with the HEI's reputation and teaching quality, accounting for $15 \%$ and $13 \%$ of the total quotations respectively. One focus group discussant summed this up in the following quote: So you see, you see that the reputation of university is what in the end of the day will make someone either goes there or not, you know. Most of us are not going to take our kids to ... University because we know that most institutions don't recognize it and don't trust the paper no matter how many times they are flashing on TV.

It is worth noting that the HE landscape in Zambia has many more private universities (i.e. 55) compared to only 7 public ones (Higher Education Authority, 2019). All the private universities in the country were established in the last twenty years; many of them lack highly qualified teaching staff, infrastructure and facilities. This could explain why reputation, teaching staff and student support preoccupy prospective students' thoughts when making university related choices. Student support (defined in terms of assistance offered to potential and existing students by various units or university staff such as lecturers, administrators and ODeL coordinators) seems to be an odd one out as a brand attribute, accounting for $13 \%$ of the total quotations. This attribute was mentioned mostly by ODeL students. Yeah, ESAMI in East Africa, in Tanzania. I found that most of the courses were the same. Research undertaken in China placed a higher premium on employability than what the current study revealed (Zhu \& Reeves, 2019). This could be attributed to the fact that the majority of ODeL students are in full time employment and located in cities where the university does 
not have a physical presence. Facilities were defined in terms of resources that HEIs use to aid and facilitate learning. Therefore, physically visiting the university to gather information to aid the decision making process is not feasible. In such a situation, student support facilities, including speedy response to potential students' queries is paramount.

\section{Figure 2: Frequency of HEI Factors for ZCAS University}

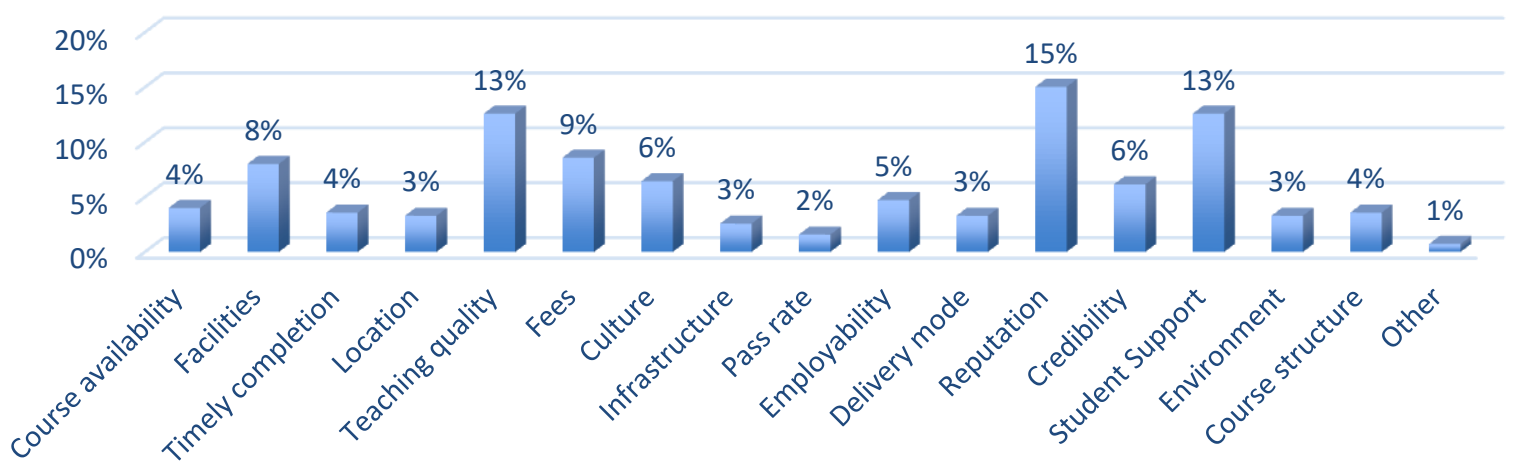

As in other studies such as (Ivy, 2008), (Cvetkoska, 2019), and (Zhu \& Reeves, 2019), the current study suggested that fees, with $9 \%$ of the total quotations, are a key consideration in choice of university. In this particular case, fees are an important factor in choice of university because most of the students are selfsponsored; therefore, fees and terms of payment affect capacity of students to pay for their programmes of study. Furthermore, most postgraduate students are breadwinners at household level; thus they have other financial obligations in addition to paying their own tuition fees. One focus group discussant, for example, expressed their concern for fees as follows: I think the other factor which is there is also the cost element of it because we don't want to just go to a place and pay so much if there's a place offering a similar service and the cost is less, you would go there without affecting the quality of education. They include libraries, computer laboratories, parking spaces, eating places, recreation facilities and teaching aids. I can say, one of my bosses did the program I think before me and she was in her last semester during the time I was starting. So she is the one who advised that actually you learn a lot if you get on this program.

So I think that was one of the people who helped me cement the decision to come back and do something else. An apparent peculiar influencer revealed by the current research is the employer. The literature review on influencers of postgraduate student choice did not identify employers as influencers of potential postgraduate students. Facilities were classified among the top 5 brand attributes that aspiring postgraduate students considered in their choice of university. This is probably because as a developing country, employers in Zambia are just satisfied with a candidate holding a master's degree, and therefore less keen to thoroughly scrutinize programme content of those qualifications. Additionally, the course content for many of the programmes is similar, as asserted by one focus group participant: I think for me I considered, first I looked at, having done a Greenwich degree, I had considered the courses under Greenwich postgraduate. I looked at ZCAS, then I looked at ESAMI. This is possibly because most postgraduate students in the university are already in employment, and therefore employability prospects are not a paramount consideration in choice of university.

Sources of Competitive Advantage for ZCAS University: In order of importance, the top 4 factors which students thought give ZCAS University a competitive edge in the postgraduate studies market were facilities, teaching quality, reputation and accreditation (see Figure 3 below). Of these, the first 3 attributes are also among the factors that preoccupy aspiring postgraduate students' HEI choices. As stated above, Zambia's higher education sector is still in its infancy; most of the HEIs are less than 20 years old and have inadequate 
highly qualified teaching staff, infrastructure and facilities. An HEI with state of the art facilities is therefore likely to stand out. In the case of ZCAS University, the competitive edge seems to be underpinned by the parent company's good reputation in the HE market. The university is wholly owned by ZCAS, an institution that has been in existence for 30 years and is well known for offering high quality education at a high premium.

\section{Figure 3: Sources of Competitive Advantage for ZCAS University}

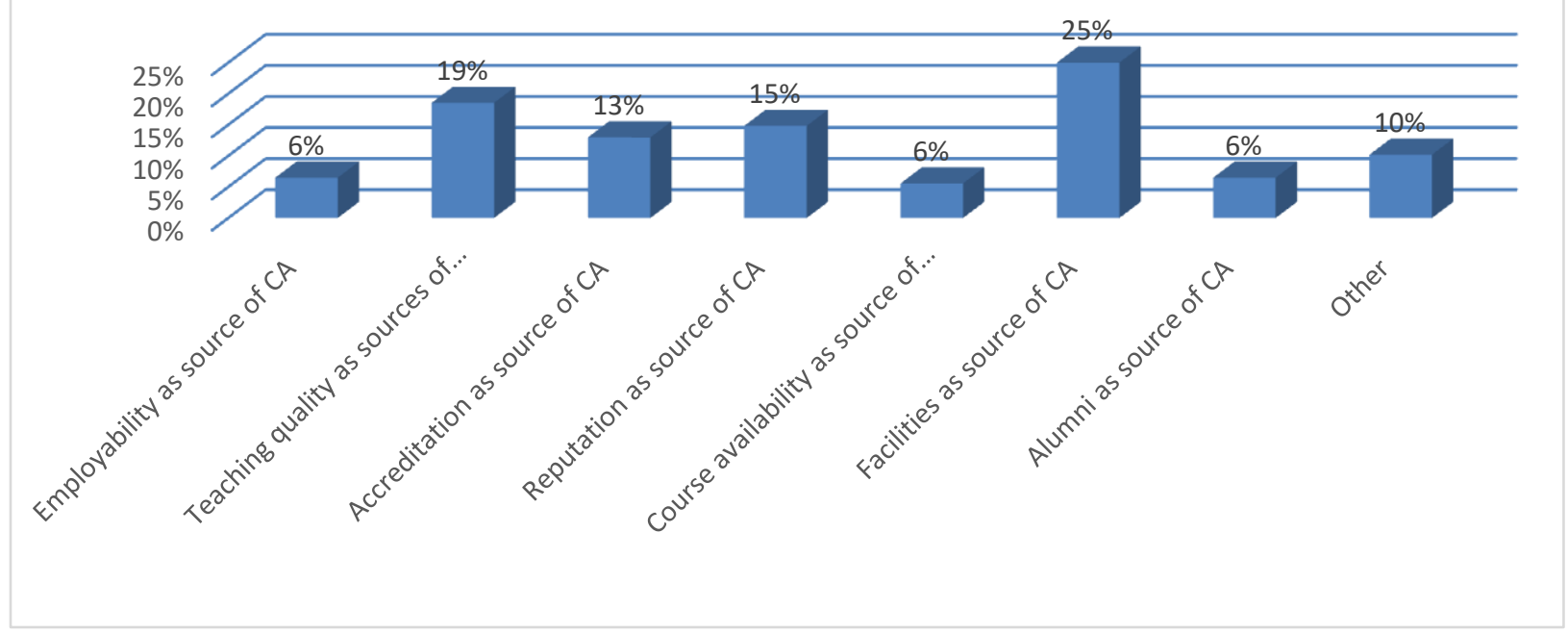

Accreditations with local and international institutions were considered to be another significant source of competitive advantage for ZCAS University. The university's parent company has been offering learning programmes in association with well renowned local and international institutions such as the University of Zambia, University of Greenwich, University of London, ACCA, CIMA etc. for many years. Many of these learning programmes are now offered in association with the university, and seem to give the institution credibility and recognition. This was echoed by 2 of the focus group respondents as follows: So, you know, the collaboration that ZCAS has like I said earlier, for you to be, to have that collaboration, it means that you have been vetted and you were found to be of high quality as an institution, so that is what I value most about ZCAS and then another thing on a personal level that I checked for was the university ranking and accreditations that the university has because accreditations will show quality. They prove that university actually has quality assurance. It gives you that assurance that okay, I am dealing with recognized, a recognized university.

Information Sources: The study revealed that websites, social media, print media and television were the most consulted information sources by prospective postgraduate students at ZCAS University (see Figure 4 below). To a lesser extent, potential postgraduate candidates sought information about the university from education expos, friends, student administration and family. Meanwhile, billboards, prospectuses and alumni were rarely consulted. The information sources identified in the current study are similar to what other researchers from other parts of the world found. For example, several researchers have observed that potential postgraduate students are increasingly turning to the internet and social media for information about universities (Galan, Lawley, \& Clements, 2015). The popularity of websites (with $26 \%$ of the 136 quotations regarding information sources) and social media (23\%) is not surprising as it reflects the increase in access to Information and Communication Technology (ICT) services in the country (Central Statistical Office and Zambia Information and Communications Technology Authority, 2018).

It also played a part in influencing my decision, which is key also. Print media (mostly newspapers) with $13 \%$ of the quotations and television (10\%) are also popular sources of information. This could be attributed to the fact that most aspiring postgraduate students are relatively older and more likely to access these sources of information compared to those seeking undergraduate study. This can be evidenced from the following comment made by a focus group respondent: People that do postgraduate, I think maybe 60 or $70 \%$ are 
managers. So, even media consumption is different from those that are trying to start to do undergraduate. These BBCs (Born before Computers) they still want to see things in hard copy, in a newspaper, in a magazine, on radio, or on TV. For example, the 2018 national survey on access and usage of ICT by households and individuals in Zambia indicated that access to internet services among households rose from $12.7 \%$ to $17.7 \%$ between 2015 and 2018. Meanwhile, $14.3 \%$ of the population said they had used the internet in the previous 3 months, compared to only $8.8 \%$ three years earlier.

Figure 4: Frequency of Information Sources in Interview and Focus Group Transcripts

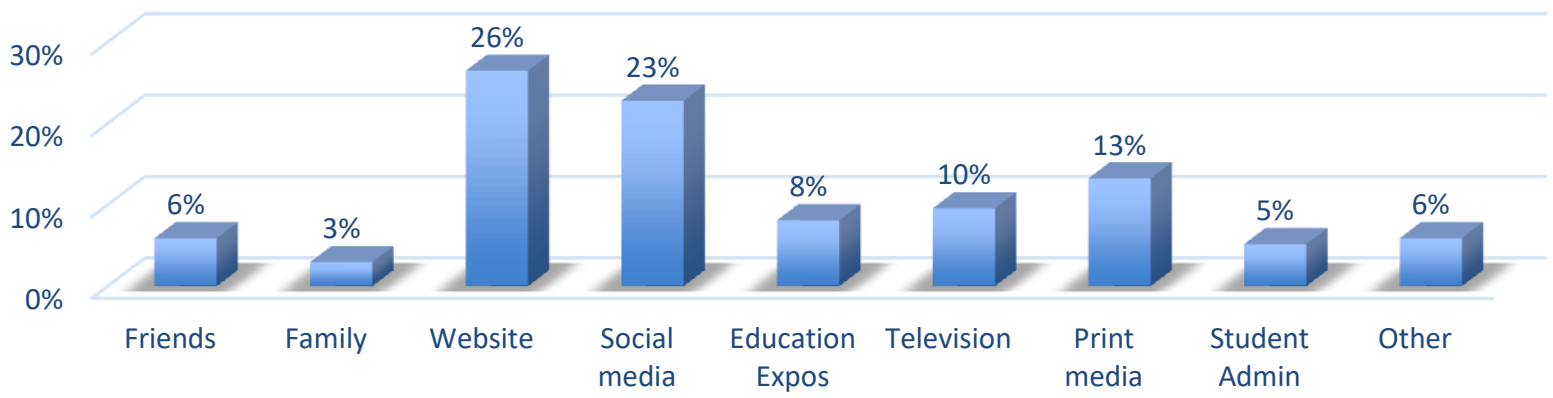

Considering that Zambia is set to increase universal coverage of both internet and communication facilities to 96\% (Mvunga, 2019), the reliance on websites and social media as key information sources by prospective postgraduate students is likely to increase. As one focus group respondent retorted, the internet is a default information source: Of course, when I heard about it of course the main source where I went to was the internet. So the traditional media should always be considered. With respect to television, the 2018 ICT survey indicated that 37\% of households in Zambia accessed television services in 2018, compared to 33\% three years earlier (Central Statistical Office and Zambia Information and Communications Technology Authority, 2018). Television is therefore likely to continue to be a valuable source of information for aspiring postgraduate candidates in the foreseeable future.

Influencers of Student Choice of ZCAS University: Findings from the study suggested that potential ZCAS University postgraduate students were highly influenced by friends when choosing the university (accounting for $35 \%$ of quotations), followed by self (20\%), workmates (18\%) and family (17\%) as shown in Figure 5 below. Other influencers of postgraduate student choice include alumni, employer, and parents, each accounting for $3 \%$ of total references.

Figure 5: Frequency of Influencers in Interview and Focus Group Transcripts

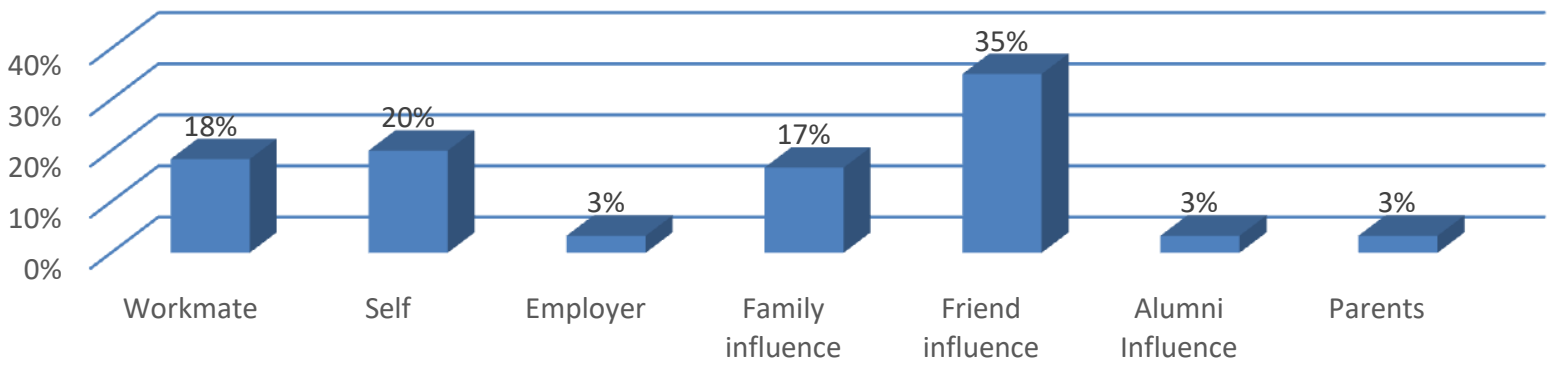


The influencers identified in this study are comparable to those unveiled by other researchers such as (Moogan, 2018), (Towers \& Towers, 2018), (Nyaribo, Prakash, \& Owino, 2012), although the degree of influence is different. Parents, for example, were identified as more prolific influencers of student choice compared to the case at ZCAS University (Moogan, 2018). It is evident from the study that most postgraduate students in Zambia are turning to their friends and workmates and/or making the final HEI choice decisions themselves. Two of the interview respondents stated this precisely as follows: For me. I think what influenced me the most was my friend who was doing the Greenwich program here at ZCAS and when I came he encouraged me to do the same. The apparent significant influence employers have on aspiring ZCAS University postgrad students could be attributed to high unemployment levels in the country compared to the other jurisdictions where similar studies were carried out. In Zambia, for example, the rate of unemployment is high, especially among the youth where it currently stands at 16\% (Zambia Statistics Agency, 2019). Accordingly, employers may directly or indirectly influence students to choose universities they consider credible.

\section{Conclusion and Recommendations}

The current study has revealed that the 10 most considered branding factors in the choice of ZCAS University by aspiring postgraduate students in order of importance were reputation, teaching quality, student support, fees, facilities, culture, credibility, employability, course availability and timely completion. In terms of competitive advantage, facilities, teaching quality, reputation and accreditations make the university stand out from the rest. Furthermore, potential postgraduate students sought information about the institution from the website, social media and print media; while friends, self, workmates and family had significant influence in choosing the university. Compared to similar studies regarding the market for master's degree students, the current research has revealed many similar findings as discussed in Section 4. However, some unique brand variables have also emerged mainly due to the fact that the country's higher education sector is still in its infancy. Concerns about the quality of service offered and credibility of the institutions are high, hence potential postgraduate students are most concerned about the reputation of the university, teaching quality, student support and facilities in the HEIs. Universities such as ZCAS that exploit these concerns get a competitive edge.

Practical Implications: It has long been established by scholars that student choice criteria of universities differs between and within developed and developing countries (Vrontis, Thrassou, \& Melanthiou, 2007). Therefore, ZCAS University's marketing strategists need to identify the specific brand variables that prospective postgraduate candidates consider in their choice of the institution and develop relevant marketing strategies. Some suggestions are outlined in the sections below.

ZCAS University Brand Variables: As discussed above, the most considered branding factors by aspiring postgraduate students at ZCAS University in order of importance are the reputation of the university, teaching quality, student support, fees and facilities.

Recommendations: To enhance its reputation further, ZCAS University management, particularly the Business Development Manager/Unit, must foster strong relationships with relevant government departments, reputable local and foreign universities, local and foreign professional bodies, employers and labor organizations. Activities that underpin such cooperation could include undertaking collaborative/joint research projects (e.g. with the Zambia Institute for Policy Analysis and Research), curriculum development (e.g. by incorporating input from business and regulatory professional associations such as chambers of commerce and industry), and staff exchange arrangements with collaborating local and international universities. Alternatively, management of the website can be assigned to a specific employee, preferably with marketing and IT knowledge. Other activities could include sponsorship of academic calendar events, organizing student internships with employers such as banks and audit firms.

Scholarship agreements with donor aided agencies that support affirmative action. In terms of student support, the university's Deputy Registrar needs to assign a specific recruitment staff to assist each potential student from initial engagement with the institution until enrolment on their programme of study. This should be applied particularly to potential students who apply online as they may not have face to face 
interaction with the university. With respect to fees, there is a general perception in the market that ZCAS University's tuition fees are higher than those charged by competitors. The university's Business Development Manager needs to change this perception by making the fees more visible to current and potential students. This could be achieved by publicizing the fees on the university's website, internet searches and social media platforms such as Facebook, LinkedIn and Google ads.

Sources of Information about ZCAS University: The study has established that potential postgraduate students are increasingly turning to the internet and social media during their information search about universities. It is equally evident that internet and social media usage is increasing in Zambia (Central Statistical Office and Zambia Information and Communications Technology Authority, 2018).

Recommendation: ZCAS University needs to revamp its website by enhancing user friendliness of the site and providing more information about the institution, its programmes, facilities, fees etc. The ICT Manager should take a leading role in this case and outsource management of the university's website to a specialist service organization. Alternatively, management of the website can be assigned to a specific employee, preferably with marketing and IT knowledge. Additionally, the Business Development Manager should increase subscriptions to relevant advertising agencies so that the university and its learning programs are made more discoverable in internet and social media searches.

Influencers of Student Choice of ZCAS University: The study has revealed that employers in Zambia have greater influence on their employees' choice of university than in other jurisdictions where similar studies have been carried out.

Recommendations: ZCAS University Business Development Manager/unit should raise the HEI's profile by engaging employers in various activities such as apprenticeship schemes, industrial attachment and curriculum development. The university should also engage in direct marketing of its learning programmes to major employers and labor organizations in the country.

\section{Limitations and Implications for Future Research}

Although this study has provided insights into the brand model that characterize postgraduate student choice of ZCAS University, it has some limitations. This implies that the findings cannot be generalized to the postgraduate market in Zambia. Studies that include more HEIs are therefore required. Firstly, the study was carried out in one private university, hence the findings may not entirely apply to other universities, let alone public ones. It has been found, for example, that variables that characterize university related choices differ among candidates aspiring to enter private and public universities in Malaysia (Songan, Sam, Tonga, Rahman, \& Wah, 2010). Therefore, further studies need to be conducted in more universities, especially public universities. Additionally, the study did not distinguish between different course delivery modes such as face to face and Open, Distance and eLearning. It is conceivable that factors relevant to postgraduate candidates seeking face to face delivered learning may be different from those relevant to students pursuing education through online or blended learning platforms. Further studies should be carried out in this vein.

\section{References}

Al Shobaki, M. J. \& Abu Naser, S. S. (2017). The Role of the Practice of Excellence Strategies in Education to Achieve Sustainable Competitive Advantage to Institutions of Higher Education-Faculty of Engineering and Information Technology at Al-Azhar University in Gaza A Model. International Journal of Digital Publication Technology, 135-157.

Ali-Choudhury, R., Bennet, R. \& Savani, S. (2009). University marketing directors' views on the components of a university brand. Int Rev Public Nonprofit Mark, 6, 11-33.

AL-Mutairi, A. \& Saeid, M. (2016). Factors affecting students' choice for MBA program in Kuwait Universities. International Journal of Business and Management, 11(3), 119-128.

Ancheh, K. S., Krishnan, A. \& Nurtjahja, O. (2007). Evaluative criteria for selection of private universities and colleges in Malaysia. Journal of International Management Studies, 2(1), 1-11. 
Badwan, J. J., Al Shobaki, M. J., Abu Naser, S. S. \& Abu Amuna, Y. M. (2017). Adopting Technology for Customer Relationship Management in Higher Educational Institutions. International Journal of Engineering and Information Systems, 20-28.

Blackburn, G. (2011). Which Master of Business Administration (MBA)? Factors influencing prospective students' choice of MBA programme - an empirical study. Journal of Higher Education Policy and Management, 33, 473-483.

Bryman, A. \& Bell, E. (2011). Business Research Methods (3rd ed.). New York: Oxford University Press.

Carter, S. \& Yeo, A. (2009). My place or yours? Perceptions of, and selection choice criteria for, higher education institutions: the case of UK and Malaysian students. International Journal of Economics and Business Research, 1(2), 165-190.

Central Statistical Office and Zambia Information and Communications Technology Authority. (2018, January 5). National Survey on Access and Usage of Information and Communication Technologies by Households and Individuals. Retrieved January 5, 2020, from Zambia Information and Communications Technology Authority: https://www.zicta

Chaguluka, C., Beharry-Ramraj, A. \& Amolo, J. (2018). International postgraduate students' perceptions of service quality. Problems and Perspectives in Management, 438-448.

Chapleo, C. (2010). What defines "successful" university brands? International Journal of Public Sector Management, 23(2), 169-183.

Chiu, R. \& Stembridge, A. (1999). How do full-time employees select part-time MBA programs in Hong Kong? SAM Advanced Management Journal, 64(2), 34-39.

Cvetkoska, V. (2019). Key Factors Influencing Students' Choice of University for Postgraduate Studies Abroad: A Multicriteria Decision Model. Journal of Contemporary Economic and Business Issues, 6(1), 31-43.

Dibb, S., Simkin, L., Pride, W. M. \& Ferrell, O. C. (2006). Marketing Concepts and Strategies (5th ed.). Boston: Houghton Mifflin.

Furey, S., Springer, P. \& Parsons, C. (2014). Positioning University as a Brand: Distinctions between the Brand Promise of Russell Group, 1994 Group, University Alliance, and Million+ Universities. Journal of Marketing for Higher Education, 24(1), 99-121.

Galan, M., Lawley, M. \& Clements, M. (2015). Social media's use in postgraduate students' decision-making journey: an exploratory study. Journal of Marketing for Higher Education, 25(2), 287-312.

Ganushchak-Yefimenko, L., Shcherbak, V. \& Nifatova, O. (2017). Managing a Project of Competitive-integrative Benchmarking of Higher Educational Institutions. Eastern-European Journal of Enterprise Technologies, 38-46.

Grzeda, M. \& Miller, G. (2009). The effectiveness of an online MBA program in meeting mid-career student expectations. The Journal of Educators Online, 6(2), 1-16.

Hemsley-Brown, J. \& Oplatka, I. (2006). Universities in a competitive marketplace - A systematic review of the literature on higher education marketing. International Journal of Public Sector Management, 19(4), 316-338.

Hemsley-Brown, J. \& Oplatka, I. (2015). University choice: what do we know, what don't we know and what do we still need to find out? International Journal of Educational Management, 29, 254-274.

Higher Education Authority. (2019). Ensuring Quality in Higher Education. Retrieved October 26, 2019, from Higher Education Authority Web Site: https://www.hea.org.zm/

Higher Education Authority. (2019, October 26). Ensuring Quality in Higher Education. Retrieved October 26, 2019, from Higher Education Authority: https://www.hea.org.zm/

Ivy, J. (2008). A new higher education marketing mix: the 7Ps for MBA marketing. International Journal of Educational Management, 22(4), 288-99.

Kayombo, K. M. (2014). The Identification, Measurement and Competitive Positioning of a Higher Education Institution Brand in Zambia: The Case of the Zambia Centre for Accountancy Studies (ZCAS). Edinburgh: Heriot-Watt University.

Kayombo, K. M. \& Carter, S. (2016). Understanding student preferences for university choice in Zambia. Journal of Education Policy, Planning \& Administration, 6(3), 1-21.

Khalifa, B., Dukhan, 0. \& Mouselli, S. (2017). Master degree under crisis: the salient motives of Business students to enroll in a postgraduate programme. International Journal of Educational Management.

Kusumawati, A. (2010). Privatisation and Marketisation of Indonesian public universities: a systematic review of student choice criteria literature. Indonesian Student International Conference, Melbourne, Australia. Melbourne. 
Lee, N. \& Lings, I. (2013). Doing Business research: A Guide to Theory and Practice. London: Sage Publications Ltd.

Liu, D. \& Morgan, W. J. (2015). Students' Decision-Making about Postgraduate Education at G University in China: The Main Factors and the Role of Family and of Teachers. Asia-Pacific Edu Res, 325-335.

Lomer, S., Papatsiba, V. \& Naidoo, R. (2018). Constructing a National Higher Education Brand for the UK: Positional Competition and Promised Capitals. Studies in Higher Education, 134-153.

Marks, J. \& Edgington, R. (2006). Motivations and barriers for women in the pursuit of an MBA degree. Graduate Management Admission Council, 1, 6-12.

Mihail, D. \& Elefterie, K. (2006). Perceived effects of an MBA degree on employability and career advancement: The case of Greece. Career Development International, 11(4), 352-361.

Moogan, Y. J. (2018). An investigation into international postgraduate students' decision-making process. Journal of Further and Higher Education.

Mvunga, C. (2019, March 6). Zambia to have $96 \%$ of universal coverage of both internet and communication facilities.

Nicholls, J., Harris, J., Morgan, E., Clarke, K. \& Sims, D. (1995). Marketing higher education: the MBA experience. The International Journal of Educational Management, 9(2), 31-38.

Nyaribo, M., Prakash, A. \& Owino, E. (2012). Motivators of choosing a management course: A comparative study of Kenya and India. The International Journal of Management Education, 10, 201-214.

Ries, A. \& Trout, J. (2001). Positioning: The Battle for Your Mind. New York: McGraw-Hill.

Robson, C. (2002). Real World Research (2nd ed.). Oxford: Blackwell.

Rydzewski, D., Eastman, J. \& Bocchi, J. (2010). Important characteristics in an MBA program: The perceptions of online MBA students. American Journal of Business Education, 3(4), 33-41.

Saiti, A., Papa, R. \& Brown, R. (2017). Postgraduate students' factors on program choice and expectation. Journal of Applied Research in Higher Education, 9, 407-423.

Saunders, M., Lewis, P. \& Thornhill, A. (2016). Research Methods for Business Students. Essex: Pearson Education Limited.

Soilemetzidis, I., Bennett, P. \& Leman, J. (2014, October 19). The Postgraduate Taught Experience Survey.

Soliman, M. \& Karia, N. (2017). Antecedents for the Success of the Adoption of Organizational ERP among Higher Education Institutions and Competitive Advantage in Egypt. Engineering, Technology \& Applied Science Research, 1719-1724.

Songan, P., Sam, H. K., Tonga, G., Rahman, M. A. \& Wah, T. K. (2010). Factors Influencing Student Choice: A Study of a Malaysian Public University. Asian Journal of University Education, 6(1), 75-89.

Towers, A. \& Towers, N. (2018). Re-Evaluating The Postgraduate Students' Course Selection Decision Making Process In The Digital Era. Studies In Higher Education, 47(2), 2-11.

Vrontis, D., Thrassou, A. \& Melanthiou, Y. (2007). Contemporary higher education student-choice model for developed countries. Journal of Business Research, 60(9), 979-989.

Wiese, M., van Heerden, N., Jordaan, Y. \& North, E. (2009). A marketing perspective on choice factors considered by South African first-year students in selecting a higher education institution. Southern African Business Review, 13(1), 39-60.

Yamane, T. (1967). Statistics: An Introductory Analysis (2nd ed.). New York: Harper and Row.

Zambia Statistics Agency. (2019, November 24). Key Indicators. Retrieved from Zambia Statistics Agency: https://www.zamstats.gov.zm/

ZCAS University. (2017). ZCAS University Strategic Plan 2018 - 2021. Lusaka: ZCAS University.

Zhu, L. \& Reeves, P. (2019). Chinese students' decisions to undertake postgraduate study overseas. International Journal of Educational Management, 33, 999-1011. 